\title{
KELEMBAGAAN AFORESTASI DAN REFORESTASI MEKANISME PEMBANGUNAN BERSIH (A/R MPB) DI INDONESIA: KASUS DI NUSA TEGGARA BARAT DAN JAWA BARAT ${ }^{1}$ (Aforestation and Reforestation Clean Development Mechanism $(A / R C D M)$ Institutions In Indonesia: Case in West Nusa Tenggara and West Java
}

\author{
Oleh / By : \\ Kirsfianti Linda Ginoga ${ }^{2}$, Mega Lugina ${ }^{3} \&$ R. Deden Djaenudin ${ }^{3}$
}

\begin{abstract}
Afforestation and Reforestation (A/R) institutions of Clean Development Mechanism (CDM) is intersting to be studied for the following reasons: (i) it needs a long process to get a Certified Emission Reduction (CER) statement, that it needs a clear guidelines in each step of its process (Yamada and Fujimori, 2003), (ii) there are large area of bare and degraded lands needed to be rehabilitated, and (iii) it can be an alternative funding for land rehabilitation and reforestation. The underlying motivation was to answer several research questions such as what form of CDM institutions needed, who are stakeholders involved in this institution and how to participate in CDM implementation. Analytical Hierarchy Process (AHP) Method was used for analysing these purposes. CDM like project in West Nusa Tenggara, dan Cianjur, West Java funded by JIFPRO (Japan International Forestry Promotion and Cooperation) were choosen for the research site.

This study shows that A/R CDM involves institutions at local, national and international levels. Local institution is an important factor in CDM A/R implementation, especially in choosing location/land for CDM which must be eligible based on Kyoto Protocol, as well as having clear ownership and low social risks. This is indicated by high priority weighted by stakeholders for land and social indicators in West Nusa Tenggara and West Java, i.e, 28\% and 31\% respectively.

The structure of $A / R C D M$ institution need to be syncronized with local social economic condition and administration system. Therefore, institutional structure in West Nusa Tenggara is different from that in West Java. In West Nusa Tenggara several stakeholders decisive in directing CDM implementation were Provincial Forest Office, Governor of West Nusa Tenggara Province and Head of East Lomboke district, Ministry of Forestry especially DG of land rehabilitation and social forestry, and JIFPRO. On the other hand, the structure of $A / R C D M$ institution in West Java involving Ministry of Forestry especially DG of land rehabilitation and social forestry, Citarum-Ciliwnng Watersehed Management Agency, and JIFPRO. Both institution involved JIFPRO as an initial funding organisation, indicating the important role of initial funding organisation for $A / R C D M$ implementation.

This study suggest the need to form local A/R CDM comission or local A/R CDM forum to coordinate, facilitate and syncronize A/RCDM activity from local to national level.
\end{abstract}

Keywords: Aforestation and Reforestation Clean Development Mechanism, institutions

\footnotetext{
${ }^{1}$ Peer Review oleh Mitra Bestari Prof. Dudung Darusman dan Dr. Upik R. Wasrin

${ }^{2}$ Peneliti Madya Pada PUSLITSOSEK Kehutanan, Bogor.

${ }^{3}$ Peneliti Pertama pada PUSLITSOSEK Kehutanan, Bogor.
} 


\begin{abstract}
ABSTRAK
Kelembagaan Mekanisme Pembangunan Bersih untuk Aforestasi dan Reforestasi (A/R MPB) menarik untuk dikaji karena berbagai hal, diantaranya: (i) siklus proses perolehan Sertifikat Penurunan Emisi yang panjang, sehingga pedoman yang jelas pada setiap tahap sangat diperlukan (Yamada dan Fujimori, 2003), (ii) lahan kosong dan terdegradasi yang perlu direhabilitasi sangat luas, dan (iii) merupakan alternative pilihan dana reboisasi yang menarik di tengah minimnya dana DR dan APBN. Bagaimana bentuk kelembagaan MPB, siapa saja lembaga yang terlibat dan apa saja yang perlu dilakukan terutama di tingkat daerah agar mekanisme pelaksanaan MPB lebih efisien dari aspek biaya dan waktu, merupakan pertanyaan-pertanyaan yang mendasari dilakukannya penelitian ini. Metode AHP digunakan sebagai alat analisis. Pre-MPB proyek di Jawa Barat dan Nusa Tenggara Barat (NTB) dengan JIFPRO (Japan International Forestry Promotion and Cooperation) sebagai investor awal dipilih sebagai lokasi penelitian.

Hasil penelitian menunjukkan bahwa kelembagaan MPB A/R harus mencakup dan melibatkan kelembagaan pada tingkat daerah, nasional dan internasional. Kelembagaan daerah sangat menentukan keberhasilan pelaksanaan MPB A/R, terutama berkaitan dengan pemilihan lokasi atau lahan MPB yang layak berdasarkan definisi Protokol Kyoto, jelas status kepemilikannya, dan tidak mempunyai resiko sosial yang tinggi. Hal ini ditunjukkan dengan tingginya bobot kepentingan indikator lahan dan indikator sosial di NTB dan jawa Barat, yaitu masing-masing $28 \%$ dan $31 \%$.

Struktur kelembagaan MPB A/R di daerah saat ini disesuaikan dengan kondisi sosial ekonomi dan sistem administrasi setempat. Karena itu struktur kelembagaan di NTB dan Jawa Barat berbeda, di NTB terdapat beberapa pihak yang mempunyai peran penentu dalam mengarahkan pelaksanaan MPB yaitu Dinas Kehutanan Propinsi, Gubernur NTB dan Bupati Lombok Timur, Departemen Kehutanan terutama Dirjen Rehabilitasi Lahan dan Perhutanan Sosial (Dirjen RLPS) serta JIFPRO. Untuk Jawa Barat hanya melibatkan Departemen Kehutanan terutama Dirjen RLPS, dan BP DAS Citarum Ciliwung, serta JIFPRO. Keduanya melibatkan JIFPRO sebagai investor awal, yang menandakan pentingnya peran investor awal dalam memulai kegiatan MPB A/R.

Hasil penelitian menyarankan perlunya dibentuk komisi daerah MPB atau forum MPB daerah yang dapat berfungsi untuk koordinasi, fasilitasi dan sinkronisasi kegiatan MPB mulai tingkat lokal sampai nasional.
\end{abstract}

Kata kunci: Mekanisme Pembangunan Bersih untuk Aforestasi dan Reforestasi, Kelembagaan

\title{
I. PENDAHULUAN
}

Protokol Kyoto (PK) Pasal 12 menyebutkan bahwa Mekanisme Pembangunan Bersih (MPB) atau Clean Development Mechanism (CDM) merupakan bentuk komitmen kemitraan antara Negara Annex 1 (negara maju) dan Non-Annex 1 (negara berkembang) untuk menurunkan emisi gas rumah kaca (GRK) melalui kegiatan kehutanan. Kegiatan kehutanan yang sudah disepakati adalah aforestasi dan reforestasi (A/R). MPB A/R dapat diterima apabila dilakukan secara sukarela oleh para pihak, kegiatannya terukur, dan merupakan upaya mitigasi terhadap perubahan iklim. Ukuran mitigasi perubahan iklim yang sudah disepakati diukur dalam ton setara $\mathrm{CO}_{2}$, dan diperdagangkan dalam bentuk sertifikat penurunan emisi (Certified Emission Reduction, CERs). Dengan telah diratifikasinya PK, melalui UU. No. 17/2004 berarti Indonesia berkomitmen terhadap pelaksanaan MPB. 
Indonesia telah mempunyai beberapa aturan operasional yang mendukung kelembagaan ${ }^{4}$ MPB A/R pada tingkat nasional seperti PP 34/2002 ${ }^{5}$ tentang Tata Hutan dan Penyusunan Rencana Pengelolaan Hutan, Pemanfaatan Hutan dan Penggunaan Kawasan Hutan, Permenhut No. P. 14/2004 tentang Tata Cara Aforestasi dan Reforestasi dalam Kerangka Mekanisme Pembangunan Bersih, SKMenLH No. 206/2005 tentang Komisi Nasional Mekanisme Pembangunan Bersih, dan Keputusan Ketua Komisi Nasional Mekanisme Pembangunan Bersih No. 1/2005 tentang Sekretariat Komisi Nasional Mekanisme Pembangunan Bersih. Karena itu bagaimana agar aturan ini dapat diimplementasikan dan disinkronkan dengan aturan MPB A/R di daerah/lokal sangat diperlukan. Kelembagaan MPB A/R menarik untuk dikaji karena berbagai hal, diantaranya: (i) siklus proses perolehan Sertifikat Penurunan Emisi panjang, sehingga pedoman yang jelas pada setiap tahap sangat diperlukan (Yamada dan Fujimori, 2003), (ii) lahan kosong dan lahan terdegradasi harus direhabilitasi sangat luas, dan masih akan terus bertambah luas, (iii) potensi dana MPB sebagai alternatif pilihan dana reboisasi menarik di tengah minimnya ketersediaan dana DR dan APBN, dan (iv) tingkat keberhasilan kegiatan reboisasi selama ini rendah dan banyak dipertanyakan karena berbagai hal antara lain seperti sistem keproyekan (Cf. Mulyana, 2005; Haeruman, 2005).

Oleh karena itu kajian tentang kelembagaan MPB A/R sangat diperlukan sebagai upaya mempersiapkan kelembagaan yang efektif (khususnya kemampuan kelembagaan untuk mencapai tujuan yang telah ditetapkan) dan efisien (mencakup rasio antara nilai output dan input). Dengan demikian diharapkan dapat tercapat keberhasilan kegiatan pembangunan dan pengelolaan hutan khususnya Aforestasi dan Reforestasi yang berkelanjutan dan berkeadilan. Kajian ini bertujuan untuk mengetahui kelembagaan dalam proses perolehan sertifikat penurunan emisi CERs, termasuk perkiraan biaya dan waktu yang diperlukan dalam perolehan sertifikat.

Penelitian ini secara umum bertujuan untuk mengkaji kelembagaan pelaksanaan MPB $\mathrm{A} / \mathrm{R}$ di Indonesia, dan perolehan sertifikat penurunan emisi mulai dari tingkat daerah/lokal, nasional dan internasional.

\footnotetext{
${ }^{4}$ Kelembagaan menurut Ruttan dan Hayami (1984) adalah aturan di dalam suatu kelompok masyarakat atau organisasi yang memfasilitasi koordinasi antar anggotanya untuk membantu mereka dengan harapan setiap orang atau organisasi mencapai tujuan bersama yang diinginkan. Sedangkan Ostrom (1985) mendefinisikan kelembagaan sebagai aturan dan rambu-rambu sebagai panduan yang dipakai oleh para anggota untuk mengatur hubungan yang saling mengikat dan tergantung satu sama lain. North (1990) lebih menekankan kelembagaan sebagai aturan main di dalam suatu kelompok yang sangat dipengaruhi oleh faktor-faktor ekonomi, sosial dan politik. Paembonan (2003), mengartikan kelembagaan sebagai perangkat aturan yang mengarahkan perilaku masyarakat dalam mencapai keterpenuhan kebutuhan masyarakat dalam kehidupan. Pada prinsipnya kelembagaan berbeda dengan organisasi, dimana kelembagan lebih kental dengan peraturan dan organisasi lebih terfokus pada struktur.

Dari definisi-definisi tersebut dapat dikatakan bahwa kelembagaan adalah aturan yang yang memfasilitasi instusi atau organisasi dalam berkoordinasi dan bekerjasama untuk mencapai tujuan bersama yang diinginkan. Aturan disini mencakup aturan formal dan non formal yang diperlukan dan disepakati bersama. Karena itu aturan disini harus jelas, terukur dan konsisten. Organisasi atau institusi yang terlibat diharapkan mempunyai sumberdaya manusia yang kredibel dan mempunyai pengetahuan serta pengertian yang cukup tentang permasalahan yang ada.

PP 34/2002 menyebutkan bahwa perdagangan karbon dapat dilakukan pada hutan produksi dan hutan lindung dengan areal maksimum 1000 ha per ijin, dan pemegang ijin baik koperasi, individu, BUMN, BUMD, dan BUMS dapat memiliki maksimum 2 ijin per propinsi, selama 10 tahun dan dapat diperpanjang.
} 


\section{METODOLOGI}

\section{A. Kerangka Analisis}

Secara umum penelitian dilakukan dengan menggunakan kerangka analisis seperti tertera pada Gambar 1. Dari Gambar 1 terlihat, bahwa kajian ini mengikuti alur proses perolehan SPE/CERs.

Input di dalam Gambar 1, adalah semua upaya yang diperlukan oleh pengembang dalam pembuatan Dokumen Rancangan Proyek (DRP). Dalam hal ini termasuk penjelasan mengenai rencana kerja, baseline, additionaliti, rencana investasi awal, perkiraan keuntungan, perencanaan untuk mengatasi kebocoran, dan persyaratan-persyaratan yang diperlukan berdasarkan berbagai peraturan yang ada.

Proses adalah tahapan mulai pembuatan DRP, persyaratan DRP, setelah DRP selesai dibuat dan diserahkan ke tingkat nasional termasuk penilaian oleh kelompok kerja Departemen Kehutanan dan KomNas MPB. Dalam hal ini proses melibatkan institusi daerah, Departemen Kehutanan, KomNas MPB dan lembaga internasional.

Output adalah hasil akhir dari pelaksanaan MPB, yakni perolehan CERs (sertifikat penurunan emisi). Seluruh kegiatan tersebut, mulai dari input, proses dan output memerlukan lembaga yang dapat mendukung perolehan Sertifikat melalui proses yang transparan dan akuntabel.

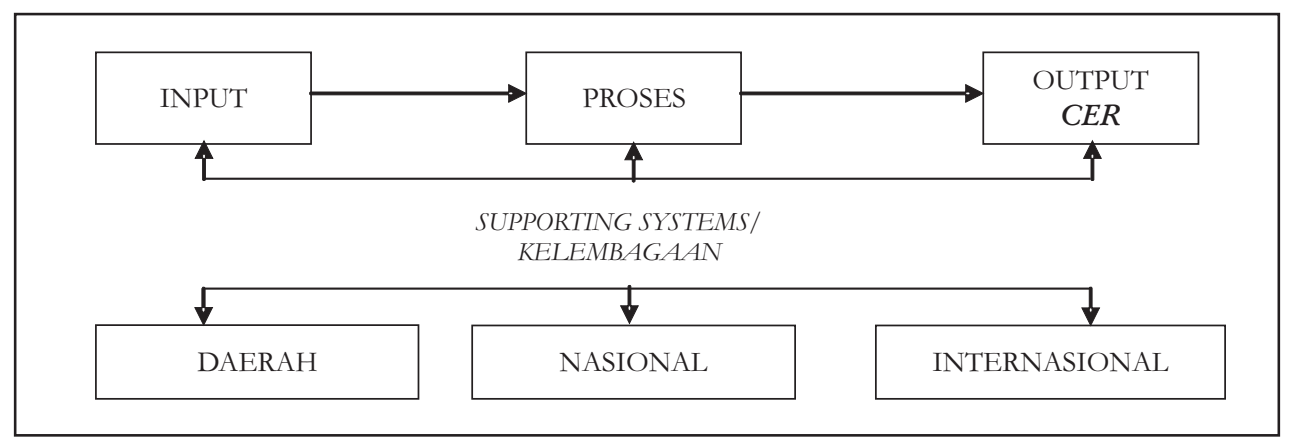

Gambar 1. Skema Sederhana Kebutuhan Kelembagaan MPB

\section{B. Pengumpulan dan Analisis Data}

Data primer diperoleh melalui pengisian kuesioner hasil wawancara atau diskusi dengan para pakar dari beberapa instansi yang berkompeten dalam bidang jasa lingkungan baik di pusat maupun di daerah, dan Lembaga Swadaya Masyarakat. Pengamatan lapangan dilakukan pada proyek percobaan MPB yang didanai oleh JIFPRO di Nusa Tenggara Barat dan Jawa Barat. Data sekunder dikumpulkan dari berbagai instansi terkait dan pencarian literatur melalui situs internet.

Untuk mengetahui tingkat efisiensi kelembagaan MPB A/R dgunakan metode penentuan skala prioritas dengan berdasarkan pada berbagai aspek yang harus dipertimbangkan (Lampiran 1) untuk selanjutnya diidentifikasi aspek mana yang menjadi prioritas. Langkah berikutnya adalah menentukan lembaga (organisasi) yang terseleksi untuk melaksanakan kebijakan MPB dan selanjutnya menentukan strategi yang harus diprioritaskan agar kebijakan tersebut dapat diterapkan. 


\section{Penentuan Skala Prioritas}

Untuk memudahkan dalam penentuan prioritas, maka langkah pertama yang harus dilakukan adalah menyusun hirarki kebijakan, yang mencakup aspek-aspek yang harus dipertimbangkan dan lembaga pelaksana. Hirarki merupakan abstraksi struktur suatu sistem yang menunjukkan interaksi fungsional antar komponen dan dampaknya terhadap sistem. Menurut Saaty (1988), tidak ada batasan tertentu mengenai jumlah tingkatan pada struktur keputusan yang terstratifikasi, dan juga jumlah elemen pada setiap tingkat keputusan. Setelah menyusun hirarki langkah kedua adalah menyusun matriks perbandingan berpasangan, seperti disajikan pada Tabel 1.

Langkah ketiga, yaitu melakukan perbandingan berpasangan. Perbandingan berpasangan antara setiap elemen pada kolom ke-i dengan setiap elemen pada baris ke-j sehubungan dengan sifat atau kriteria tertentu $G$ dilakukan dengan analisis: seberapa kuat elemen baris ke-i memiliki atau berkontribusi, mendominasi, mempengaruhi, memenuhi, atau menguntungkan terhadap kriteria $\mathrm{G}$ dibandingkan dengan elemen kolom ke-j.

Tabel 1. Matriks Perbandingan Berpasangan

\begin{tabular}{|c|c|c|c|c|}
\hline$G$ & $F_{1}$ & $F_{2}$ & $\ldots$ & $F_{n}$ \\
\hline$F_{1}$ & $F_{11}$ & $f_{12}$ & $\ldots$ & $f_{n 1}$ \\
\hline$F_{2}$ & $F_{21}$ & $f_{22}$ & $\ldots$ & $f_{n 2}$ \\
\hline$\ldots$ & $\ldots$ & $\ldots$ & $\ldots$ & $\ldots$ \\
\hline$F_{n}$ & $f_{n 1}$ & $f_{n 2}$ & $\ldots$ & $f_{n n}$ \\
\hline
\end{tabular}

dimana :

$\mathrm{G}=$ Kriteria sebagai dasar pembandingan

$\mathrm{F}_{\mathrm{i}}, \mathrm{F}_{\mathrm{i}}=$ Elemen ke-i atau ke-j dari level satu di bawah level yang memuat $\mathrm{G}$ (kriteria nilai perdagangan)

$\mathrm{i}, \mathrm{j}=1,2, \ldots, \mathrm{n}$ adalah indeks elemen yang terdapat pada level yang sama dan secara bersama-sama terkait dengan kriteria $G$

$\mathrm{f}_{\mathrm{ij}} \quad=$ Angka yang diberikan dengan membandingkan elemen ke-i dengan elemen ke- $\mathrm{j}$ sehubungan dengan sifat $G$, yang didasarkan dari aturan skala banding berpasangan pada Tabel 1 .

Pengisian matriks perbandingan berpasangan dengan angka, berupa nilai bandingnya, dilakukan untuk menggambarkan secara relatif pentingnya suatu elemen dibanding dengan elemen lainnya berkenaan dengan sifat tertentu dengan menggunakan skala banding yang terdapat pada Tabel 2. Pengisian matriks dengan menggunakan skala banding hanya dilakukan untuk bagian yang ada di sebelah kiri atas diagonal, sedang disebelah kanan bawah diagonal diisi nilai kebalikannya. Bila $F_{i}$ lebih mendominasi sifat $G$ dibandingkan dengan $F_{j}$, maka angka bulat 1 - 9 yang digunakan. Bila $F_{\mathrm{i}}$ kurang mendominasi sifat $\mathrm{G}$ dibandingkan dengan $\mathrm{F}_{\mathrm{i}}$, maka angka kebalikannya yang digunakan. 
Tabel 2. Skala Dasar Perbandingan

\begin{tabular}{|c|l|}
\hline Intensitas Tingkat Kepentingan & \multicolumn{1}{c|}{ Definisi } \\
\hline 1 & Sama penting \\
\hline 3 & Sedikit lebih penting \\
\hline 5 & Lebih penting \\
\hline 7 & Sangat lebih penting \\
\hline 9 & Mutlak lebih penting \\
\hline $2,4,6,8$ & $\begin{array}{l}\text { Nilai Tingkat kepentingan yang mencerminkan suatu } \\
\text { nilai kompromi }\end{array}$ \\
\hline & $\begin{array}{l}\text { Nilai tingkat kepentingan jika dilihat dari arah yang } \\
\text { berlawanan. } \\
\text { Misalnya jika A sedikit lebih penting dari B (intensitas } \\
\text { 3), maka berarti B sedikit kurang penting dibanding A } \\
\text { (intensitas 1/3) }\end{array}$ \\
\hline
\end{tabular}

\section{Lokasi Penelitian}

Penelitian dilakukan di Kabupaten Lombok Timur, Propinsi Nusa Tenggara Barat dan Kabupaten Cianjur, Propinsi Jawa Barat (Gambar 2). Kedua lokasi ini dipilih, karena terdapat kegiatan JIFPRO (Japan International Forestry Promotion and Cooperation Centre) yang akan diajukan sebagai Proyek MPB Skala kecil (Small Scale CDM), dengan JIFPRO sebagai investor awal. Karena itu, lokasi ini diharapkan dapat mewakili sebagai objek dan lokasi proses pelaksanaan MPB.

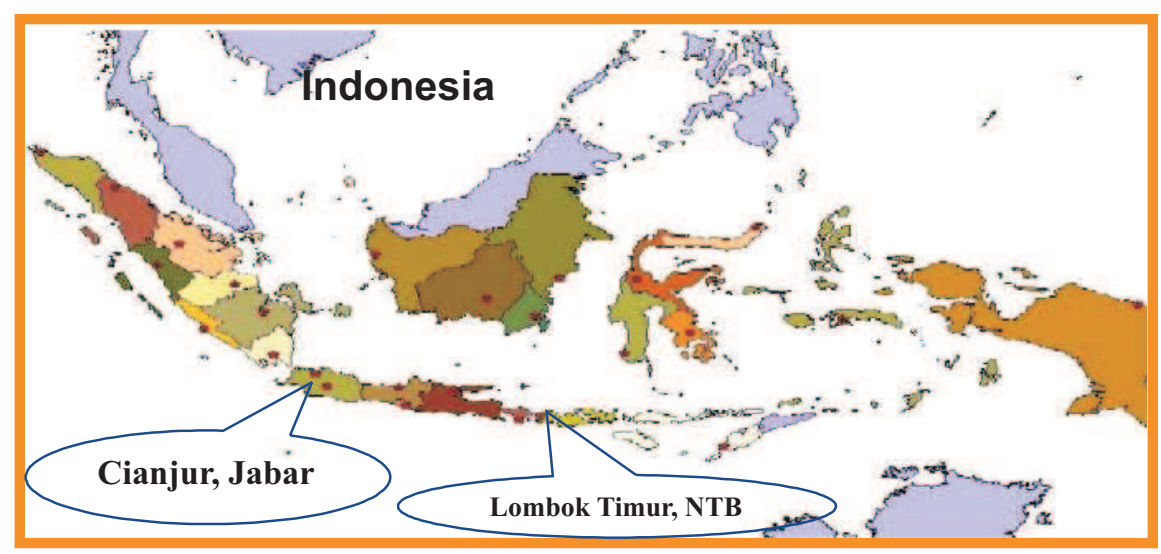

Gambar 2. Lokasi Penelitian 


\section{HASIL DAN PEMBAHASAN}

\section{A. Kelembagaan MPB}

Ada tiga kelembagaan yang berperan dalam mendukung pelaksanaan MPB A/R di Indonesia, yaitu pertama Kelembagaan MPB lokal pada tingkat daerah yaitu propinsi dan kabupaten, kedua Kelembagaan nasional yakni Kelompok Kerja MPB Kehutanan di Departemen Kehutanan dan KomNas MPB, serta ketiga Kelembagaan Internasional.

\section{Kelembagaan MPB Lokal}

Kelembagaan MPB lokal dengan investor awal adalah JIFPRO di Nusa Tenggara Barat dan Jawa Barat sebagaimana terlihat pada Gambar 3. Untuk kelembagaan di NTB terlihat ada beberapa pihak yang menjadi komisi pengarah MPB di NTB yakni Gubernur NTB dan Bupati terkait lokasi MPB yang akan dilaksanakan yakni di Kabupaten Lombok Timur, Dinas Kehutanan Propinsi yang akan menjadi proyek koordinator, Departemen Kehutanan melalui Dirjen Rehabilitasi Lahan Perhutanan Sosial (RLPS) serta investor awal dalam hal ini JIFPRO (Japan International Forestry Promotion and Cooperation). Unit pelaksana proyek akan dimonitor dan dievaluasi langsung oleh Dinas Kehutanan Propinsi yang berkoordinasi dengan dinas kehutanan kabupaten sebagai supervisor tim teknis.

Berbeda dengan kelembagaan di NTB, untuk Jawa Barat hanya melibatkan dua pihak yaitu JIFPRO dan Departemen Kehutanan (Dirjen RLPS dan BP DAS Citarum-Ciliwung) sebagai komisi pengarah. Di sini juga tidak melibatkan Dinas Kehutanan Propinsi maupun Gubernur, hanya melibatkan Dinas Kehutanan (Dinas Perhutanan dan Konservasi Tanah) Kabupaten Cianjur. Unit pelaksana terdiri dari tiga pelaksana proyek yakni administrasi, perencanaan dan pembinaan yang keseluruhannya beranggotakan staf BP DAS CitarumCiliwung.
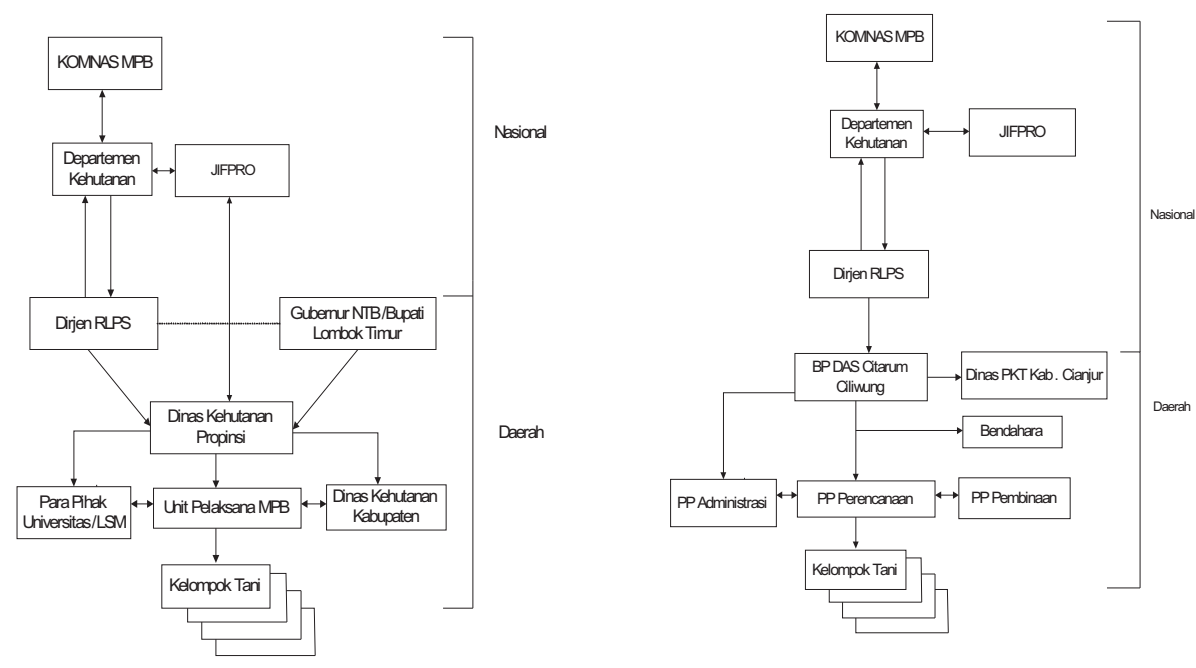

Keterangan: Digambar berdasarkan hasil analisis di lapangan

Gambar 3. Kelembagaan Lokal Proyek Pre MPB di Lombok Timur dan Cianjur

Kelembagaan Aforestasi dan Reforestasi

(Kirsfianti Linda Ginoga et al.) 
Kurangnya pelibatan daerah dalam proyek ini menyebabkan daerah (dalam hal ini Dinas PKT) mengalami kesulitan pada saat mereka ditanyai mengenai kegiatan JIFPRO. Dalam kegiatannya terkadang BP DAS langsung menghubungi kelompok tani dan inilah yang menyulitkan Dinas PKT dalam memantau kegiatan proyek. Terdapat kesan bahwa BP DAS mengerjakan hampir semua kegiatan pelaksanaan proyek dan pengambilan keputusan. Kurangnya koordinasi di tingkat propinsi dan kabupaten serta tidak adanya pelibatan LSM dan perguruan tinggi menyebabkan banyak instansi baik di tingkat propinsi maupun kabupaten tidak mengetahui adanya proyek yang didanai JIFPRO dan dengan demikian pengawasan dari pihak luar yang dapat mendukung keberhasilan proyek tidak berjalan. Padahal keberadaan proyek ini sangat potensial untuk diketahui orang banyak dalam rangka mensosialisasikan MPB.

\section{Kelembagaan Nasional}

(i) Kelompok Kerja MPB Departemen Kehutanan

Menanggapi permintaan pemerintah Indonesia agar setiap sektor memperoleh manfaat dari MPB maka Departemen Kehutanan mengeluarkan Peraturan Pemerintah No. 14 tahun 2004 yang secara spesifik mengatur pelaksanaan proyek MPB A/R di Indonesia. Isi utama dari peraturan pemerintah tersebut adalah: i). definisi hutan, aforestasi dan reforestasi dalam kerangka proyek MPB, ii). identifikasi pihak-pihak yang berkompeten menjadi pengembang proyek MPB A/R, iii). memvalidasi prosedur bagi pemerintah kabupaten dalam menentukan lahan yang layak untuk kegiatan proyek MPB, dan iv). prosedur yang harus ditempuh untuk memperoleh ijin dan surat rekomendasi dari Departemen Kehutanan yang menyatakan bahwa proyek MPB A/R yang diajukan memberikan manfaat bagi pembangunan hutan berkelanjutan. Surat dari Departemen Kehutanan harus dilampirkan pada setiap desain rancangan proyek (DRP) MPB A/R.

Proses untuk memperoleh surat rekomendasi dari Departemen Kehutanan dijelaskan pada Gambar 4. Sebagai tambahan, peraturan pemerintah memberikan kewenangan kepada Departemen Kehutanan untuk membentuk Kelompok Kerja MPB A/R untuk memfasilitasi dan memberikan bimbingan bagi pihak terkait dan pengembang proyek dalam mempersiapkan dan/atau mengevaluasi proyek MPB A/R. Kelompok kerja harus menjamin bahwa proyek MPB A/R yang diajukan sesuai dengan kebijakan kehutanan nasional dan mendukung pengelolaan hutan berkelanjutan.

\section{(ii) Komisi Nasional MPB (KomNas MPB)}

Pemerintah Indonesia membentuk Komisi Nasional Mekanisme Pembangunan Bersih (KomNas MPB) sebagai DNA nasional pada tanggal 22 Agustus 2005 yang secara resmi dibuka pada bulan September 2005. KomNas MPB ini bertanggung jawab terhadap semua hal yang berkaitan dengan MPB di Indonesia, Komisi Nasional (KomNas) sebagai lembaga otoritas nasional (designated national authority, DNA) yang mempunyai tugas memberikan persetujuan atas Usulan Proyek MPB, termasuk kolaborasi antar organisasi. KomNas MPB terdiri dari National Executive Board (NEB) yang beranggotakan seluruh sektor yang relevan di tingkat nasional, yaitu Kementrian Lingkungan Hidup, Departemen Energi dan Mineral, Departemen Kehutanan, Departemen Industri, Departemen Luar Negeri, Departemen Dalam Negeri, Departemen Perhubungan, Departemen Pertanian dan Badan Perencanaan dan Pembangunan Nasional. 


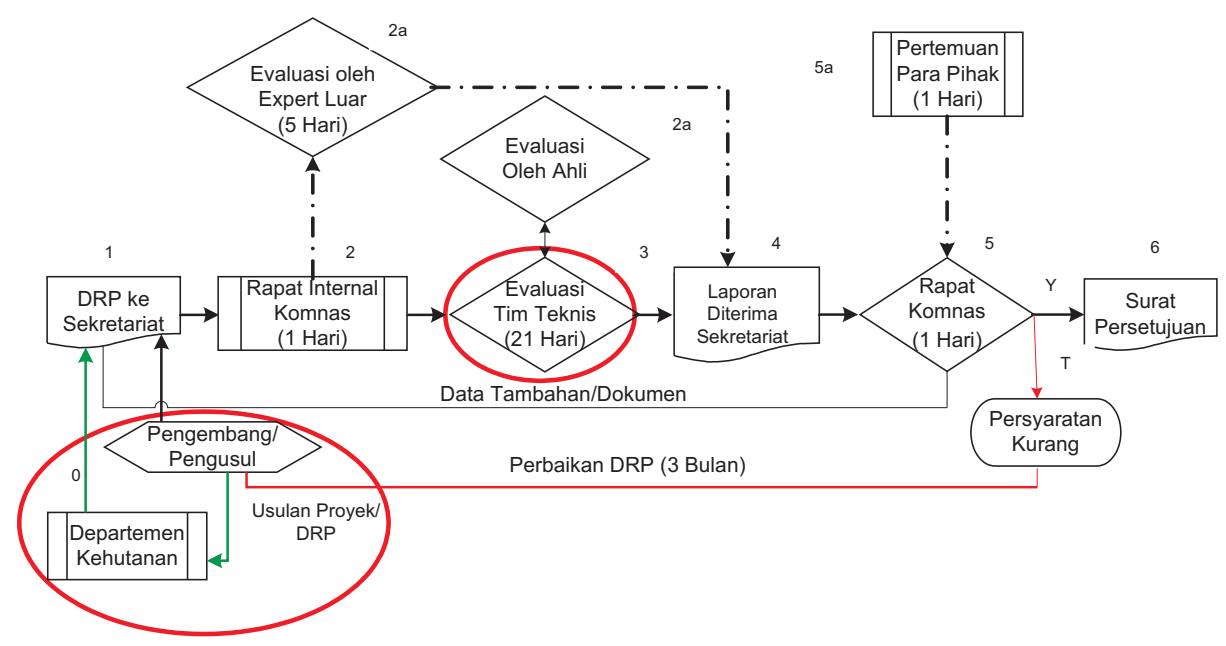

Gambar 4. Proses Perolehan Surat Persetujuan dari Departemen Kehutanan dan KomNas MPB di Tingkat Nasional

Keterangan :

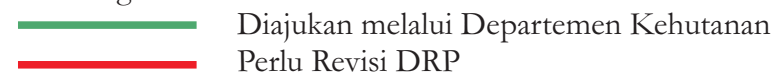

Dalam menjalankan fungsinya KomNas MPB dibantu oleh: i) tim teknis tetap (TT'T) dan tidak tetap ('T'T'T), dan ii) sekretariat. Tim teknis mempunyai tugas melakukan evaluasi teknis setiap Usulan Proyek dalam kerangka pemenuhan kriteria indikator pembangunan berkelanjutan, serta menyampaikan hasil evaluasi dan rekomendasi teknis kepada Komnas MPB melalui sekretariat. Sekretariat MPB berkedudukan di Kementerian Negara Lingkungan Hidup di bawah Deputi yang membidangi masalah perubahan iklim. Peranan dari setiap komponen dalam Komnas ini dapat dilihat pada Tabel 3. T'T'T terdiri dari perwakilan seluruh sektor dan LSM.

Tabel 3. Peranan dan Fungsi Setiap Komponen Pada KomNas MPB

\begin{tabular}{|l|l|l|}
\hline \multicolumn{1}{|c|}{ Komponen } & \multicolumn{1}{c|}{ Peranan } & \multicolumn{1}{c|}{ Tugas } \\
\hline KomNas MPB & DNA Indonesia & $\begin{array}{l}\text { Semua tugas dan fungsi } \\
\text { DNA }\end{array}$ \\
\hline $\begin{array}{l}\text { National Executive Board } \\
\text { NEB) }\end{array}$ & $\begin{array}{l}\text { Menjalankan dan } \\
\text { memfasilitasi tugas KomNas }\end{array}$ & Menyetujui DRP \\
\hline Sekretariat & Adminstrasi DRP & $\begin{array}{l}\text { Menerima dan komunikasi } \\
\text { DRP }\end{array}$ \\
\hline T'TT (\& TT'TT) & Tim Teknis dan Review & $\begin{array}{l}\text { Evaluasi dan rekomendasi } \\
\text { Teknis DRP }\end{array}$ \\
\hline
\end{tabular}




\section{Kelembagaan Internasional}

Lembaga internasional yang terlibat dalam pelaksanaan MPB kehutanan adalah CDM Executif Board (Badan Eksekutif MPB) yang mengeluarkan CERs dan Entitas Operasional (EO) yang sudah diakreditasi oleh Badan Eksekutif MPB yang melakukan validasi dan verifikasi kebenaran kegiatan MPB.

Secara umum kelembagaan untuk memperoleh SPE/CERs dapat dilihat pada Gambar 5. Sedangkan penjelasan setiap tahap untuk memperoleh SPE/CERs diuraikan pada Tabel 4.

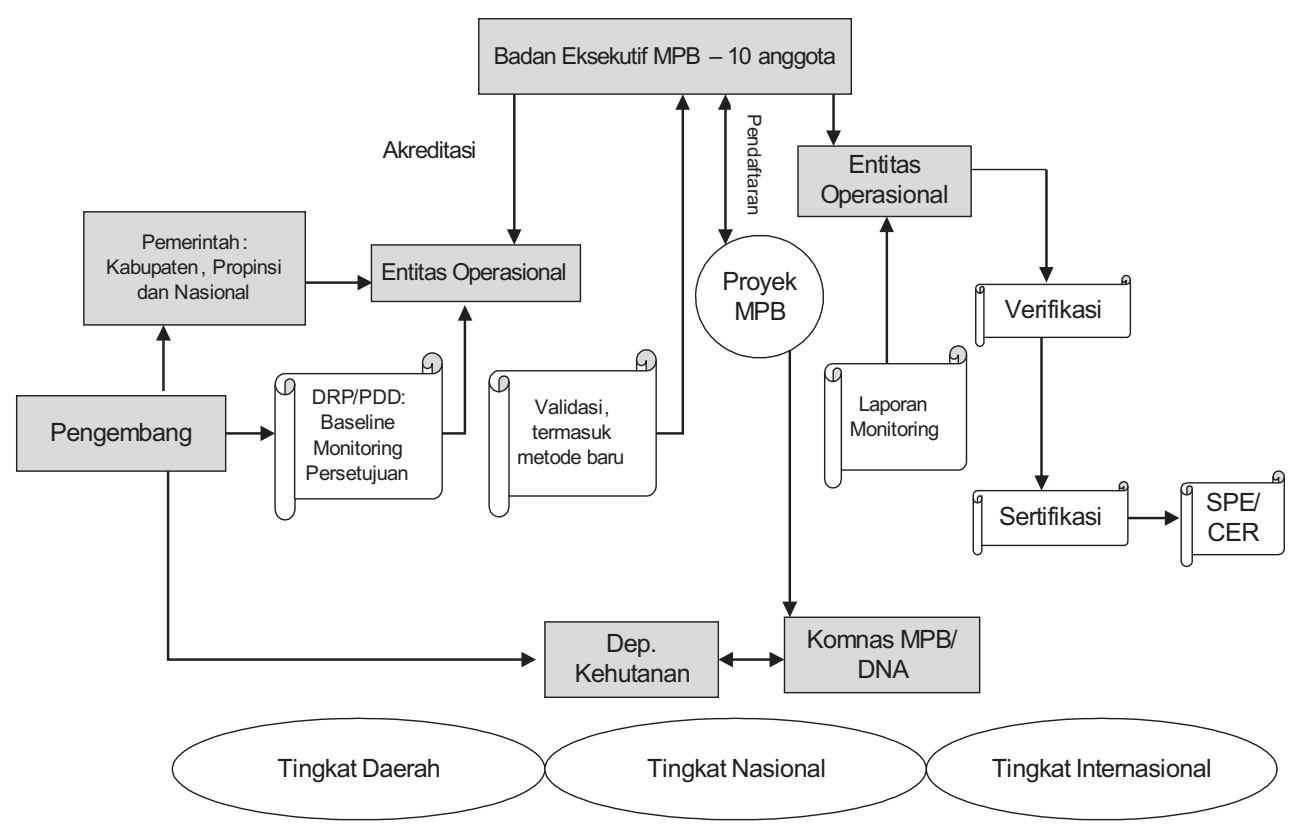

Gambar 5. Proses Perolehan SPE Karbon dan Kelembagaan MPB di Indonesia

Seperti digambarkan pada Tabel 4, tahapan untuk memperoleh SPE/CERs, masingmasing adalah :

1. Pembuatan Dokumen Rancangan Proyek (DRP)

Syarat keharusan untuk pembuatan DRP yaitu:

1) areal memenuhi syarat kelayakan lahan untuk reforestasi, yaitu sejak tanggal 31 Desember 1989 bukan merupakan hutan ${ }^{6}$,

2) surat keterangan kepemilikan lahan,

3) surat keterangan lahan untuk MPB, yang membuktikan bahwa lahan tersebut bebas dari konflik serta mempunyai kepemilikan lahan yang jelas,

4) peta lokasi dengan skala 1:10.000 serta batas lokasi untuk kegiatan MPB,

${ }^{6}$ Definisi hutan untuk MPB adalah luas lahan minimal 0.25 ha, penutupan kanopi minimal $30 \%$ dan tinggi pohon minimal pada saat masak tebang adalah $5 \mathrm{~m}$. 
5) informasi situasi dan kondisi lahan dan tata gunanya sejak 1989 sampai sekarang, hal ini didasarkan pada informasi yang akurat seperti peta dan berita acara, dan

6) surat pernyataan dukungan masyarakat dan para pihak terkait dalam kegiatan MPB.

Perlunya persyaratan ini dikuatkan oleh pendapat dari responden penelitian di NTB, yang menyatakan bahwa kejelasan lahan akan sangat mempengaruhi kelangsungan kegiatan MPB. Disebutkan bahwa aspek kejelasan kepemilikan lahan dianggap mempunyai resiko tertinggi terhadap kegagalan proyek MPB di NTB, karena kejelasan status lahan berhubungan langsung dengan keberhasilan tanaman.

Tabel 4. Matriks Tahapan Sertifikat Penurunan Emisi (SPE atau CERs)

\begin{tabular}{|c|c|c|c|c|}
\hline No. & Tahap & Organisasi & Kelembagaan & Persyaratan \\
\hline 1. & \begin{tabular}{l|} 
Dokumen \\
Rancangan \\
Proyek (DRP)
\end{tabular} & $\begin{array}{l}\text { Pengusul/Pengembang } \\
\text { (Perseorangan, Swasta, } \\
\text { Koperasi, BUMN, } \\
\text { BUMD) }\end{array}$ & $\begin{array}{l}\text { Daerah/ } \\
\text { Nasional }\end{array}$ & $\begin{array}{l}\text { Surat Keterangan lahan } \\
\text { MPB dari Bupati/Camat } \\
\text { Peta skala 1:10 } 000 \\
\text { Surat kepemilikan lahan } \\
\text { Usulan Proyek } \\
\text { Ijin Usaha Pengelolaan } \\
\text { Jasa Lingkungan/Ijin } \\
\text { Usaha Pengusahaan } \\
\text { Hasil Hutan Kayu } \\
\text { untuk Kawasan hutan } \\
\text { Hak Guna Usaha untuk } \\
\text { Tanah negara } \\
\text { Surat Keterangan Tanah } \\
\text { untuk Tanah milik } \\
\text { Hak Kelola Adat untuk } \\
\text { Hutan adat }\end{array}$ \\
\hline 2. & $\begin{array}{l}\text { Persetujuan } \\
\text { DRP }\end{array}$ & $\begin{array}{l}\text { Pengusul kepada } \\
\text { Menhut dan Komnas } \\
\text { MPB }\end{array}$ & Nasional & $\begin{array}{l}\text { DRP dengan format } \\
\text { MPB } \\
\text { Surat Keterangan } \\
\text { Menteri Kehutanan }\end{array}$ \\
\hline 3. & Validasi DRP & $\begin{array}{l}\text { Lembaga Operasional } \\
\text { atas permintaan } \\
\text { pengembang }\end{array}$ & Internasional & $\begin{array}{l}\text { Surat Keterangan } \\
\text { Menhut bahwa DRP } \\
\text { yang diusulkan } \\
\text { mempunyai kontribusi } \\
\text { terhadap pembangunan } \\
\text { kehutanan yang } \\
\text { berkelanjutan } \\
\text { Surat } \\
\text { Keterangan/Persetujuan } \\
\text { Komnas MPB bahwa }\end{array}$ \\
\hline
\end{tabular}

Kelembagaan Aforestasi dan Reforestasi

(Kirsfianti Linda Ginoga et al.) 
Tabel 4. (Lanjutan)

\begin{tabular}{|c|c|c|c|c|}
\hline No. & Tahap & Organisasi & Kelembagaan & Persyaratan \\
\hline & & & & $\begin{array}{l}\text { DRP yang diusulkan } \\
\text { berkontribusi terhadap } \\
\text { pembangunan yang } \\
\text { berkelanjutan } \\
\text { Dana tersedia untuk } \\
\text { melakukan validasi } \\
\text { lapangan }\end{array}$ \\
\hline 4. & $\begin{array}{l}\text { Penyampaian } \\
\text { hasil validasi/ } \\
\text { Pendaftaran }\end{array}$ & $\begin{array}{l}\text { Lembaga Operasional } \\
\text { ke Badan Pelaksana } \\
\text { MPB }\end{array}$ & Internasional & $\begin{array}{l}\text { DRP terbukti valid } \\
\text { dengan kondisi lapangan }\end{array}$ \\
\hline 5. & Pelaksanaan & Pengembang & Daerah & $\begin{array}{l}\text { DRP disetujui Badan } \\
\text { Pelaksana MPB } \\
\text { Dana tersedia untuk } \\
\text { melakukan kegiatan } \\
\text { reforestasi }\end{array}$ \\
\hline 6. & Monitoring & Pengembang & Daerah & $\begin{array}{l}\text { Kesiapan apa dan } \\
\text { bagaimana proses } \\
\text { monitoring } \\
\text { Dana tersedia untuk } \\
\text { kegiatan monitoring } \\
\text { Dilaporkan kepada } \\
\text { Lembaga Operasional }\end{array}$ \\
\hline 7. & $\begin{array}{l}\text { Verifikasi dan } \\
\text { sertifikasi }\end{array}$ & $\begin{array}{l}\text { Lembaga Operasional } \\
\text { kepada Badan } \\
\text { Pelaksana MPB }\end{array}$ & Internasional & $\begin{array}{l}\text { Laporan monitoring dari } \\
\text { Pengembang } \\
\text { Dana tersedia } \\
\text { Verifikasi memenuhi } \\
\text { persyaratan }\end{array}$ \\
\hline 8. & $\begin{array}{l}\text { Penerbitan } \\
\text { Sertifikat } \\
\text { Penurunan } \\
\text { Emisi (CERs) }\end{array}$ & $\begin{array}{l}\text { Badan Pelaksana MPB } \\
\text { kepada Pengembang }\end{array}$ & Internasional & $\begin{array}{l}\text { Peraturan yang berlaku } \\
\text { dipenuhi }\end{array}$ \\
\hline
\end{tabular}

Keadaan lahan di NTB yang tidak subur merupakan hambatan lain yang menyebabkan daya tumbuh tanaman sangat rendah sehingga untuk mencapai target proyek perlu dana tambahan dari MPB. Karena itu, surat keterangan kelayakan lahan dari Bupati/Camat dianggap paling penting, sehingga resiko kegagalan akibat adanya klaim lahan atau kebocoran dapat diminimalisasi.

Berbeda dengan NTB, di Jawa Barat, untuk indikator resiko sosial menempati urutan tertinggi khususnya kekurangtahuan masyarakat mengenai kegiatan MPB. Ditambah dengan kondisi tingkat pendidikan dan kepemilikan lahan yang rendah sehingga diperlukan penyebarluasan informasi kepada masyarakat tentang adanya kegiatan MPB Kehutanan. 
Indikator lahan berada di urutan kedua. Hal ini karena kepemilikan lahan umumnya adalah milik sendiri dengan rata-rata kepemilikan lahan oleh masyarakat yang relatif kecil, yaitu 0,5 sampai 2 ha per petani. Sehingga sulit untuk menyediakan lahan yang cukup luas untuk proyek MPB.

Untuk NTB dan Jawa Barat, indikator ekonomi menempati urutan ketiga. Dari segi perekonomian dengan adanya kegiatan MPB yang melibatkan masyarakat diharapkan akan menambah pendapatan masyarakat. Indikator lingkungan menempati urutan terakhir, yang berarti resiko lingkungan paling kecil dan justru dengan adanya proyek MPB diharapkan kondisi lingkungan di sekitar lokasi proyek akan membaik. Gambar 6 menunjukkan bobot kepentingan bagi beberapa responden di NTB dan Jawa Barat.

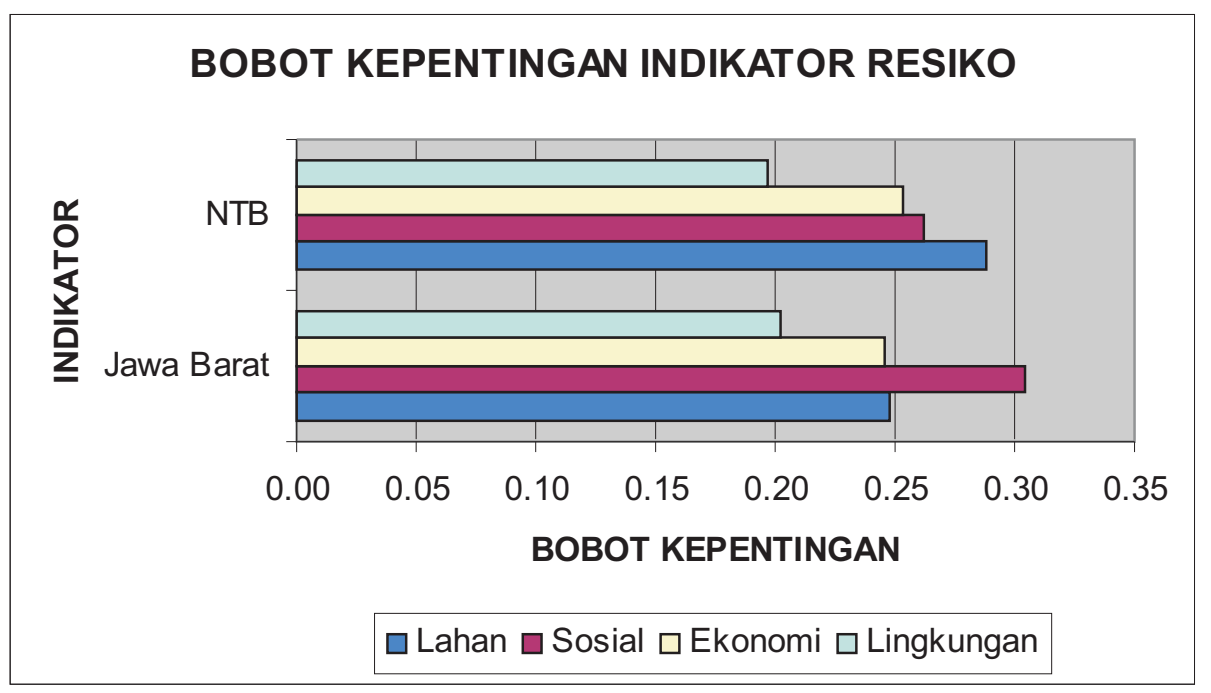

Gambar 6. Bobot Kepentingan Indikator Resiko

Pembuatan DRP dimulai dengan menyusun usulan proyek yang dapat digunakan sebagai dasar penawaran kegiatan kepada investor yang tertarik dan mengurus ijin usaha pengelolaan jasa lingkungan (IUPJL) apabila kegiatan akan dilaksanakan pada lahan kawasan. IUPJL ini dikeluarkan oleh daerah sesuai dengan arahan kriteria dan indikator pengelolaan jasa lingkungan dari Departemen Kehutanan. Sebelum ketentuan kriteria dan indikator dari pusat ini ada, daerah diberi keleluasaan untuk menetapkan persyaratan ijin pengelolaan jasa lingkungan. Secara rinci kelembagaan yang terlibat dalam pembuatan DRP dan persyaratannya dapat dilihat pada Tabel 5. 
Tabel 5. Stakeholder Terkait dengan Pembuatan Dokumen Rancangan Proyek

\begin{tabular}{|c|c|c|c|}
\hline No. & Lembaga & Lokasi & Tugas \\
\hline 1. & $\begin{array}{l}\text { Pengembang/ } \\
\text { Pengusul }\end{array}$ & $\begin{array}{l}\text { Daerah/ } \\
\text { Pusat }\end{array}$ & $\begin{array}{l}\text { Membuat Usulan Proyek dan DRP } \\
\text { dilengkapi dengan: } \\
\text { Surat keterangan lahan dari } \\
\text { Bupati/Camat } \\
\text { Surat kepemilikan lahan } \\
\text { Peta lahan dengan skala 1:10.000 } \\
\text { Informasi tentang situasi dan kondisi } \\
\text { lahan sejak tahun } 1989 \text { sampai sekarang } \\
\text { Surat keterangan adanya dukungan } \\
\text { masyarat dan para pihak terkait lainnya }\end{array}$ \\
\hline 2. & $\begin{array}{l}\text { Gubernur/Bupati/ } \\
\text { Camat }\end{array}$ & Daerah & $\begin{array}{l}\text { Mengeluarkan Surat Keterangan Lahan } \\
\text { untuk MPB } \\
\text { Mengeluarkan IUPJL }\end{array}$ \\
\hline 3. & Dinas Kehutanan & Daerah & $\begin{array}{l}\text { Verifikasi lahan dan IUPJL, } \\
\text { IUPHHK/HGU/Sertifikat Tanah }\end{array}$ \\
\hline 4. & $\begin{array}{l}\text { Menteri Kehutanan } \\
\text { melalui kelompok } \\
\text { kerja MPB }\end{array}$ & Pusat & $\begin{array}{l}\text { Ketentuan Kriteria dan Indikator IUPJL } \\
\text { Mengeluarkan IUPHHK } \\
\text { Mengeluarkan surat keterangan bahwa } \\
\text { usulan kegiatan MPB mendukung } \\
\text { pembangunan kehutanan yang } \\
\text { berkelanjutan }\end{array}$ \\
\hline 5. & $\begin{array}{l}\text { Bapeda/Bapedalda/ } \\
\text { Universitas }\end{array}$ & Daerah & Monitoring Kegiatan/Nara Sumber \\
\hline
\end{tabular}

\section{Persetujuan DRP}

Apabila proses dan persyaratan di tingkat lokal selesai, Usulan Proyek dengan semua kelengkapannya diserahkan ke Departemen Kehutanan untuk memperoleh Surat Keterangan dari Menteri Kehutanan bahwa usulan kegiatan MPB yang diajukan akan memberikan kontribusi terhadap pembangunan kehutanan yang berkelanjutan. Setelah Surat Keterangan ini diperoleh, pengusul dapat menyerahkan DRP ke KomNas MPB, untuk memperoleh persetujuan DRP. DRP tersebut minimal memuat: (i) uraian umum tentang kegiatan proyek, (ii) baseline dan additionality, (iii) rencana monitoring dan penghitungan pengurangan emisi, (iv) dampak proyek terhadap lingkungan, sosial dan ekonomi, dan (v) komentar dari lembaga-lembaga terkait.

\section{Validasi DRP}

Validasi dilakukan terhadap DRP yang telah disetujui oleh KomNas MPB. Validasi dilakukan oleh Lembaga operasional yang telah diakreditasi oleh Badan Pelaksana MPB. Kegiatan validasi ini apabila dilakukan oleh lembaga Entitas Operasional internasional akan memerlukan biaya tinggi dan waktu yang relatif lama, oleh karena itu ketersediaan dana untuk membayar lembaga operasional mutlak diperlukan. 


\section{Pendaftaran}

Pendaftaran dilakukan oleh lembaga operasional kepada badan pelaksana MPB, berdasarkan hasil validasi di lapangan.

\section{Pelaksanaan/Monitoring}

Setelah terdaftar di Badan Pelaksana MPB, kegiatan MPB dapat dilaksanakan. Penggunaan dana dilakukan sesuai dengan kesepakatan dalam DRP. Monitoring kegiatan dilakukan sesuai dengan rencana dalam DRP. Hasil monitoring disampaikan kepada lembaga operasional untuk dilakukan verifikasi.

\section{Verifikasi dan Sertifikasi}

Verifikasi dilakukan berdasarkan laporan kegiatan monitoring. Beberapa hal yang akan diverifikasi adalah additionality dari aspek serapan karbon, dampak sosial, dan dampak ekonomi. Hasil verifikasi yang telah sesuai dengan kegiatan monitoring diserahkan kepada badan pelaksana MPB untuk diterbitkan sertifikat penurunan emisi.

\section{Penerbitan Sertifikat Penurunan Emisi}

Sertifikat penurunan emisi dikeluarkan oleh Badan Pelaksana MPB. Sertifikat ini menjadi jaminan bahwa kegiatan MPB dengan jumlah serapan karbon tertentu layak untuk dijual ke pasar atau ditawarkan ke Negara Annex 1, dan pengembang mendapat insentif dari karbon yang dihasilkan.

\section{KESIMPULAN DAN SARAN}

\section{A. Kesimpulan}

Hasil penelitian menunjukkan bahwa dari tiga kelembagaan MPB Kehutanan, daerah, nasional dan internasional, kelembagaan di daerah sangat menentukan keberhasilan pelaksanaan MPB Kehutanan, terutama berkaitan dengan pemilihan lokasi/lahan MPB yang bebas konflik, layak berdasarkan definisi Protokol Kyoto dan tidak mempunyai resiko sosial yang tinggi, seperti kepadatan penduduk, pendidikan, dan kepemilikan lahan.

Bentuk dan komponen kelembagaan MPB Kehutanan daerah saat ini disesuaikan dengan kondisi sosial ekonomi dan sistem administrasi setempat. Karena itu bentuk kelembagaan di NTB dan Jawa Barat berbeda, di NTB terdapat lebih banyak pihak yang mempunyai peran penentu dalam mengarahkan pelaksanaan MPB yaitu investor awal (JIFPRO), Dirjen Rehabilitasi Lahan Perhutanan Sosial serta Gubernur NTB dan Bupati. Untuk Jawa Barat hanya melibatkan dua pihak yaitu JIFPRO dan Departemen Kehutanan (Dirjen RLPS dan BP DAS Citarum-Ciliwung).

\section{B. Saran}

Kajian ini menyarankan perlunya dibentuk forum MPB/Komisi daerah MPB yang diharapkan dapat berfungsi untuk koordinasi, fasilitasi dan sinkronisasi kegiatan MPB mulai dari tingkat lokal sampai tingkat nasional. 


\section{DAFTAR PUSTAKA}

Ando, K. 2005. Manual for the Preparation and Implementation of AR-CDM Project Activities in Indonesia. Carbon Fixing Forest Management, Bogor. Indonesia.

CIFOR. 2005. Perangkat Hukum Proyek Karbon Hutan di Indonesia. Carbon Brief No.3 Januari. Center for International Forestry Research. Bogor. Indonesia.

CIFOR. 2005. Penyusunan Dokumen Rancangan Proyek Aforestrasi/Reforestrasi Mekanisme Pembangunan Bersih. Carbon Brief No.1 Februari. Center for International Forestry Research. Bogor. Indonesia.

Kementerian Lingkungan Hidup, 2003. Kajian Strategi Nasional Mengenai Mekanisme Pembangunan Bersih di Sektor Kehutanan. Jakarta.

Ginoga, K. L., Djaenudin, D., Sarsito, A. 2003. Mekanisme Pembangunan Bersih (MPB) Kehutanan: Suatu Pengertian Awal. Sekretariat CDM Departemen Kehutanan, Jakarta.

Ginoga, K., Lugina, M., Djaenudin, D., Parlinah, N. 2004. Kajian Kebijakan Mekanisme Pembangunan Bersih (MPB) Kehutanan di Indonesia. Jurnal Sosial Ekonomi Kehutanan. Vol.1, Agustus Th. 2004. Bogor. Indonesia.

Haeruman, H. 2005. Pembentukan Lembaga Keuangan Alternatif untuk Restorasi Hutan, Pengelolaan Hutan Lestari dan Pengentasan Kemiskinan yang Progreasif. Lokakarya Nasional Inovasi Pembiayaan untuk Menyelamatkan Hutan Tropika Indonesia.

Murdiyarso, D. 2003. CDM: Mekanisme Pembangunan Bersih. Penerbit Buku Kompas, Jakarta.

North DC. 1990. Institutions, Instutional Change and Economic Performance. Cambrige University Press, Cambrige.

Ostrom, E. 1985. Formulating the elements of institutional analysis. Paper presented to conference on Institutional Analysis and Development. Washington D.C. May 21-22, 1985.

Panjiwibowo, C. Soejachmoen M. H., Tanujaya, O. dan Wisnu Rusmatoro. 2003. Mencari Pohon Uang: CDM Kehutanan di Indonesia. Pelangi. Jakarta.

Pasific Consultants. 2004. Project Cycle in Sink CDM. Presentasi pada JIFPRO Seminar on the Sink CDM, Februari 24-6. Tokyo.

Prasetyo, F.A. 2005. Sertifikasi Hutan di Indonesia dan Tantangan ke Depan. Dalam Sertifikasi di Simpang Jalan. CV.Qalam Yogyakarta.

Ruttan VW and Hayami, Y. 1984. Toward a theory of induced institutional innovation. Journal of Development Studies. Vol. 20:203-33.

Saaty, T.L. 1988. Decision Making for Leaders: The Analytical Hiearchy Process for Decision in a Complex Word. University of Pittsburg. Pittsburgh.

Sekretariat CDM. 2003. Status Penelitian dan Kajian tentang CDM Kehutanan dan Proyek Karbon Berbasis Hutan Lainnya di Indonesia. Sekretariat CDM Departemen Kehutanan, Jakarta. 
Sub Direktorat Pemanfaatan Energi Direktorat Energi Baru Terbarukan Dan Konservasi Energi. Direktorat Jenderal Listrik Dan Pemanfaatan Energi. 2002. Perspektif Clean Development Mechanism pada Proyek Energi Terbarukan dan Efisiensi Energi. http://www.dilpe.esdm.go.id/Link\%20Kiri/Dle/CDM.pdf

Sekretariat CDM. 2003. Status Penelitian dan Kajian tentang CDM Kehutanan dan Proyek Karbon berbasis hutan lainnya di Indonesia. Departemen Kehutanan. Jakarta. Indonesia.

Yamada, K. dan Fujimori, M. 2003. Technical Procedures for CDM Project Design. Mitigation and Adaption Strategies for Global Change, 8:221-235. 


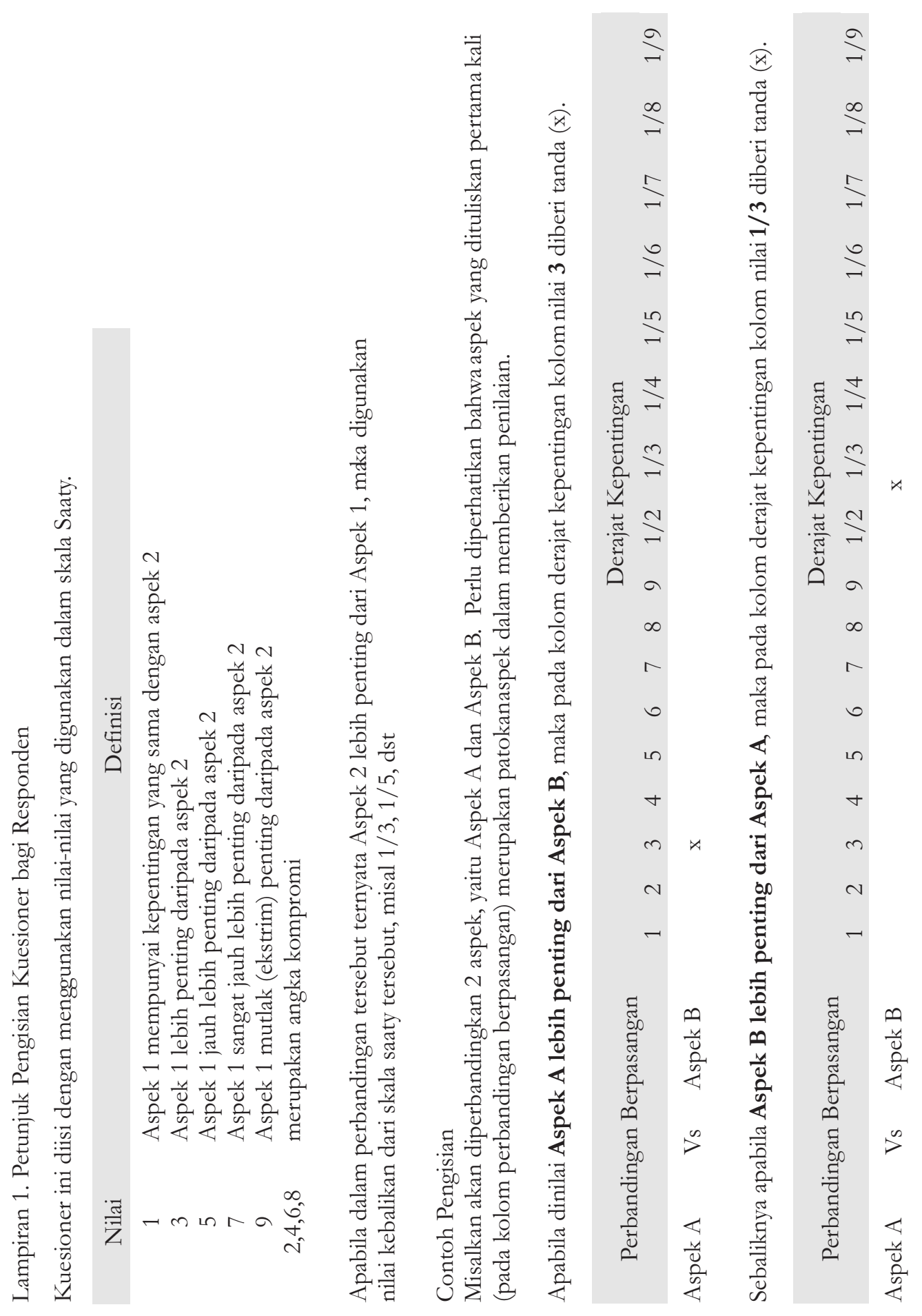




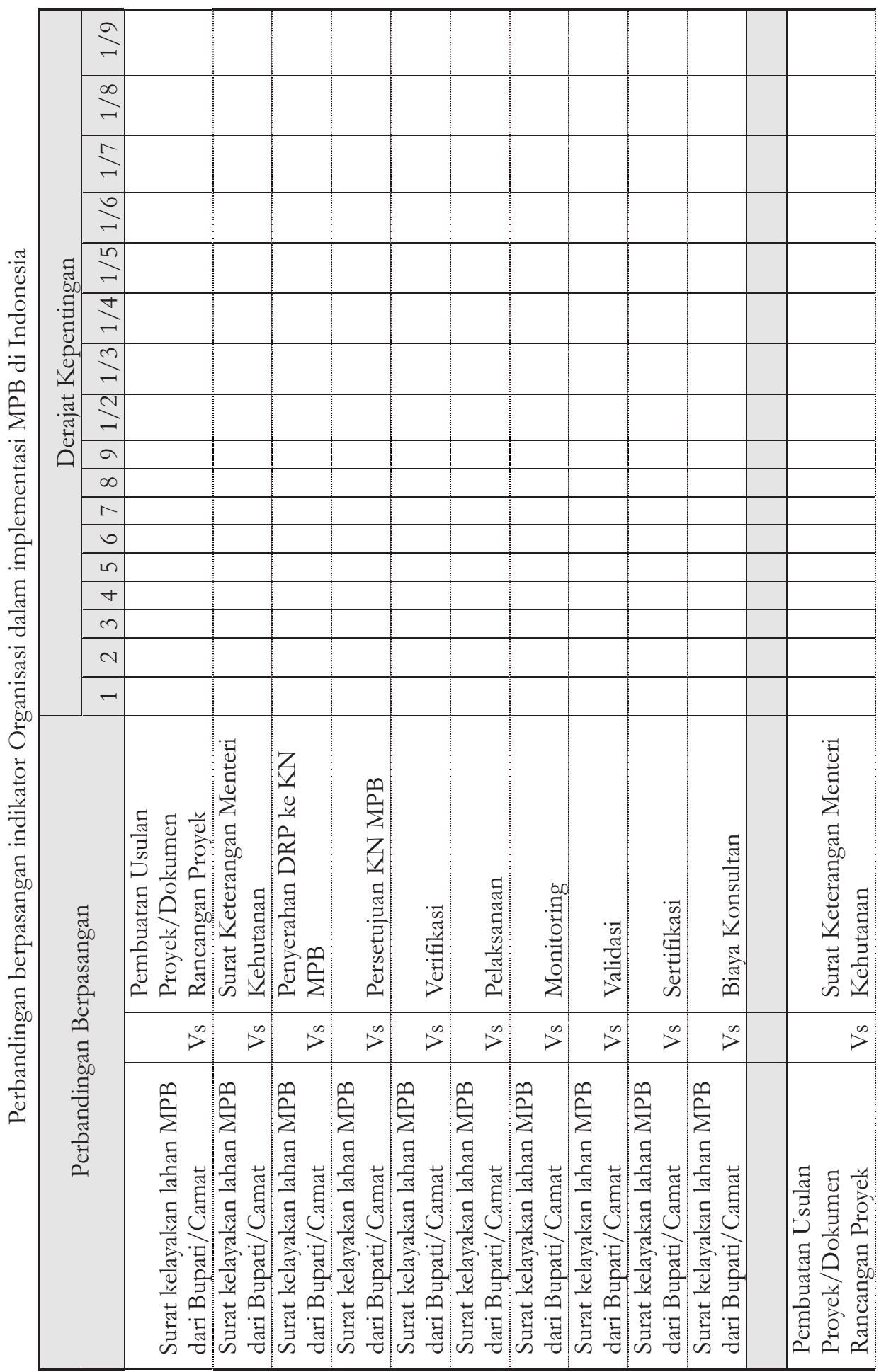




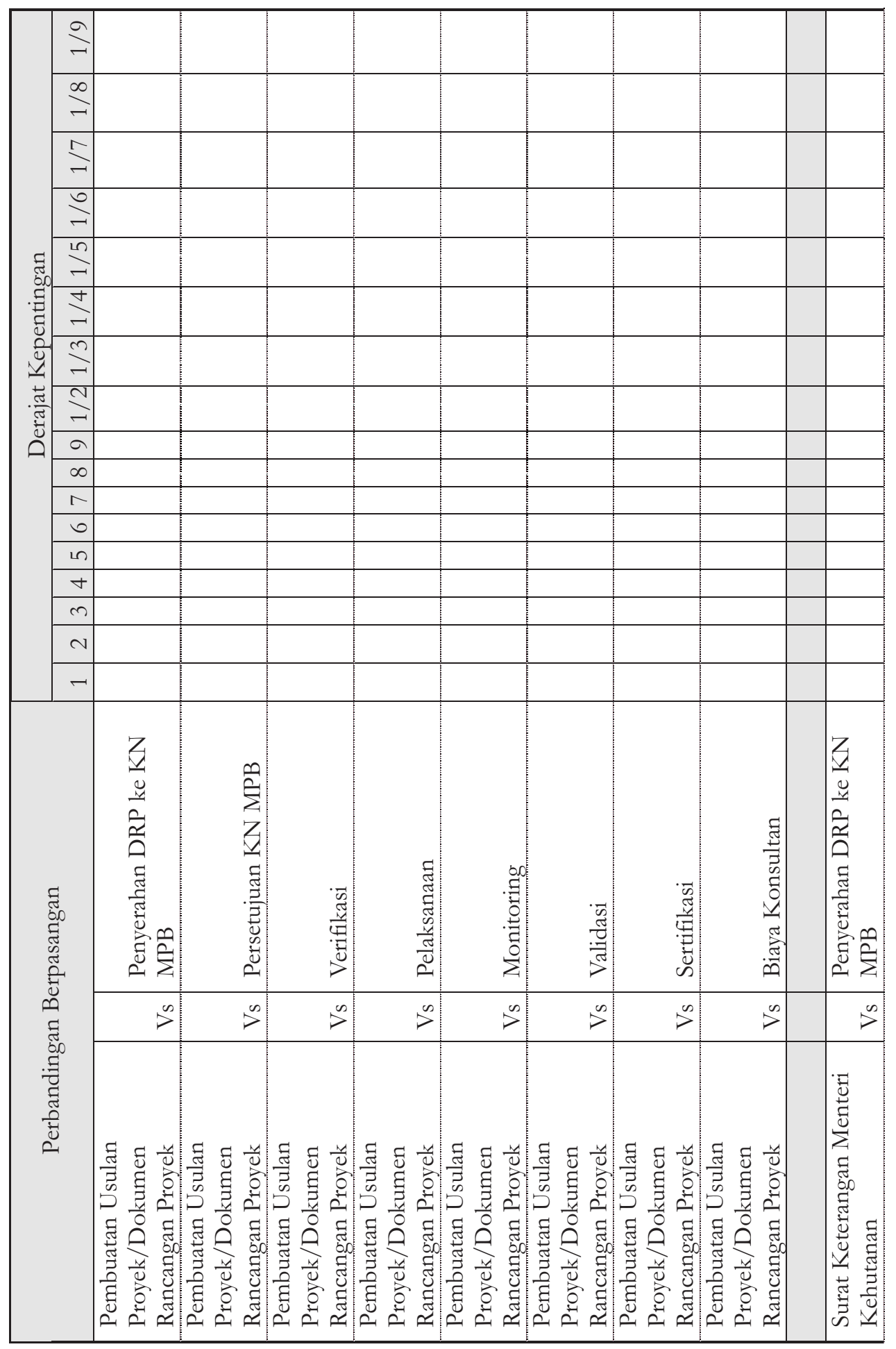




\begin{tabular}{|c|c|c|c|c|c|c|c|c|c|c|c|c|c|}
\hline$\stackrel{2}{\nearrow}$ & $=$ & & & & & & & & & & & & \\
\hline$\stackrel{\infty}{-\infty}$ & & & & & & & & & & & & & \\
\hline & & & & & & & & & & & & & \\
\hline$\stackrel{\circ}{-}$ & & & & & & & & & & & & & \\
\hline 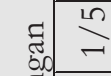 & & & & & & & & & & & & & \\
\hline 窇 & & & & & & & & & & & & & \\
\hline 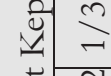 & & & & & & & & & & & & & \\
\hline 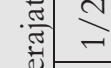 & & & & & & & & & & & & & \\
\hline 0 & & & & & & & & & & & & & \\
\hline$\infty$ & & & & & & 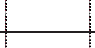 & & & & & & & \\
\hline 0 & & & & & & & & & & & & & \\
\hline in & & & & & & & & & & & & & \\
\hline$\nabla$ & & & & & & & & & & & & & \\
\hline$m$ & & & & & & & & & & & & & \\
\hline$N$ & & & & & & & & & & & & & \\
\hline- & & & & & & & & & & & & & \\
\hline 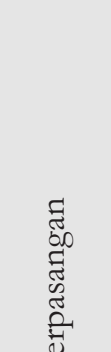 & 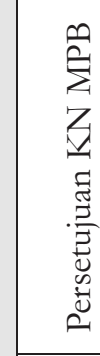 & 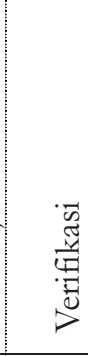 & 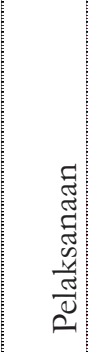 & 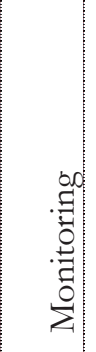 & $\begin{array}{l}\vec{g} \\
\vec{\pi} \\
\vec{\nabla} \\
\bar{\nu}\end{array}$ & 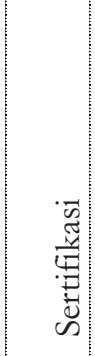 & 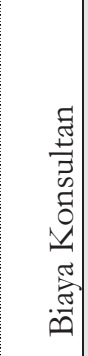 & 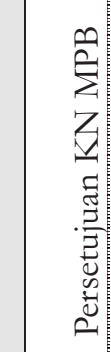 & 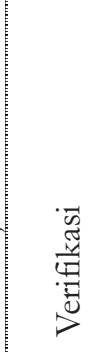 & 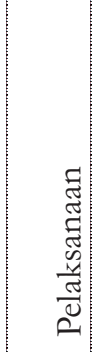 & 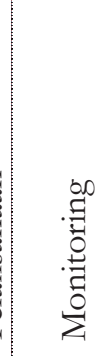 & $\begin{array}{l}\vec{y} \\
\frac{\pi}{\pi} \\
\frac{\pi}{n}\end{array}$ & 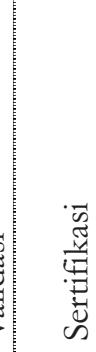 \\
\hline$\underset{\text { D }}{\infty}$ & $>^{\infty}$ & $>^{\infty}$ & $s^{\infty}$ & $>^{\infty}$ & $p^{\infty}$ & $>^{\infty}$ & $p^{\infty}$ & $p^{\infty}$ & $>^{\infty}$ & $p^{\infty}$ & $\infty^{\infty}$ & $p^{\infty}$ & $>^{\infty}$ \\
\hline 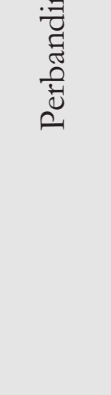 & 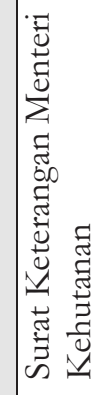 & 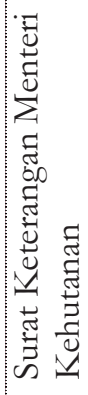 & 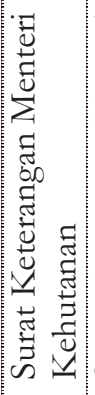 & 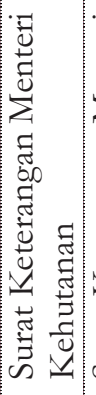 & 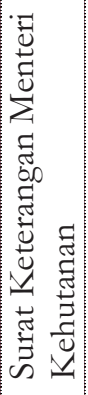 & 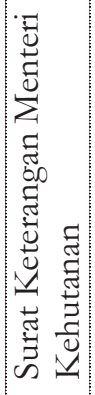 & 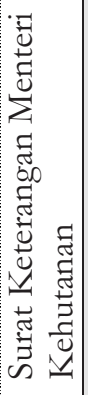 & 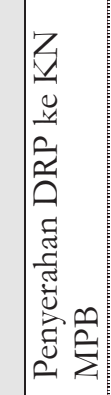 & 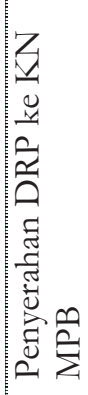 & 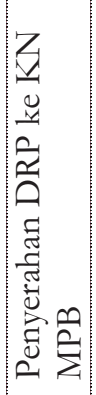 & 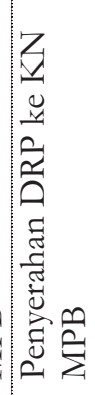 & 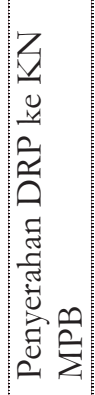 & 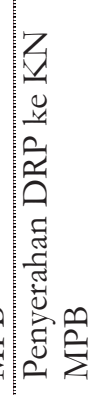 \\
\hline
\end{tabular}




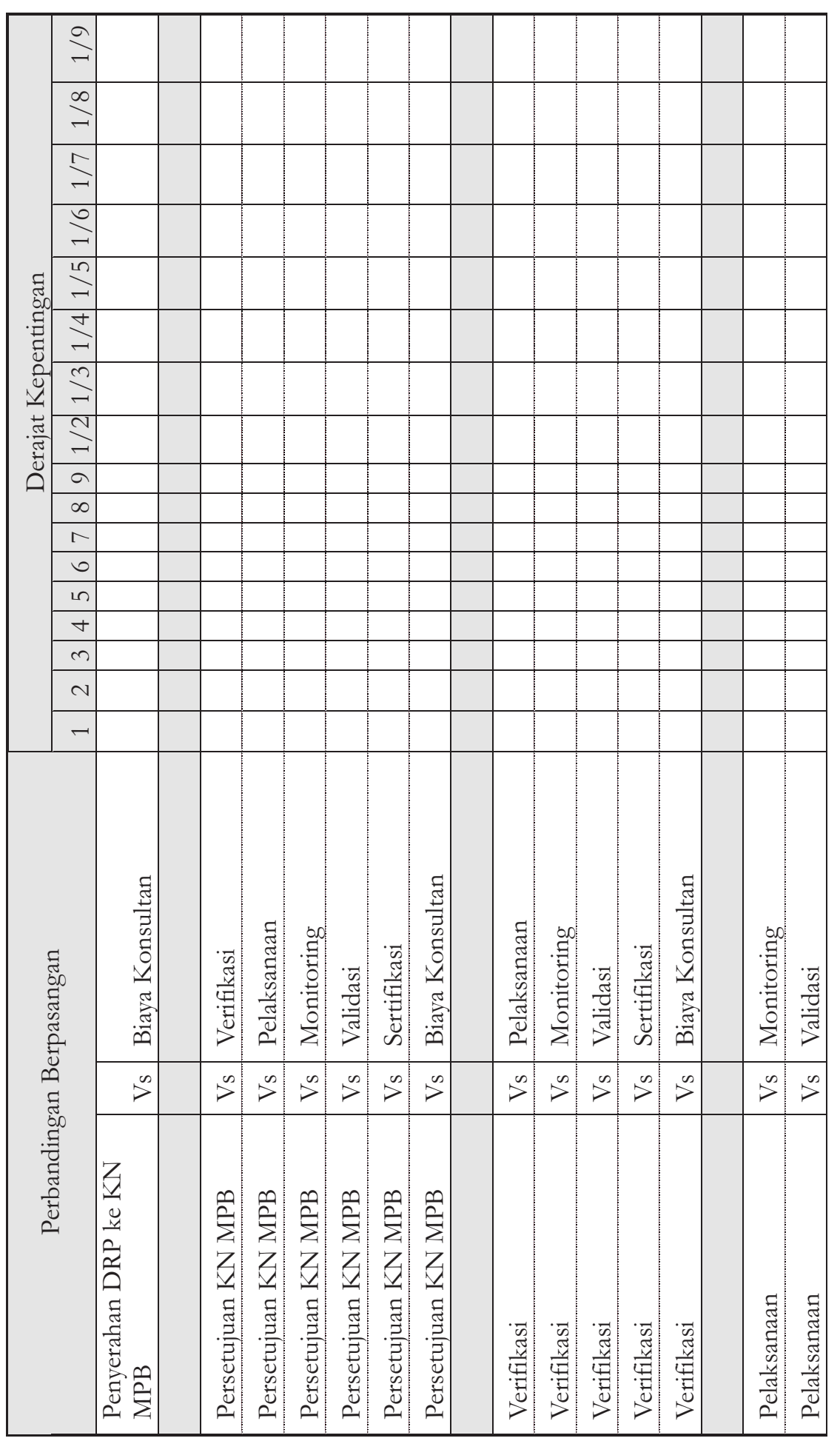




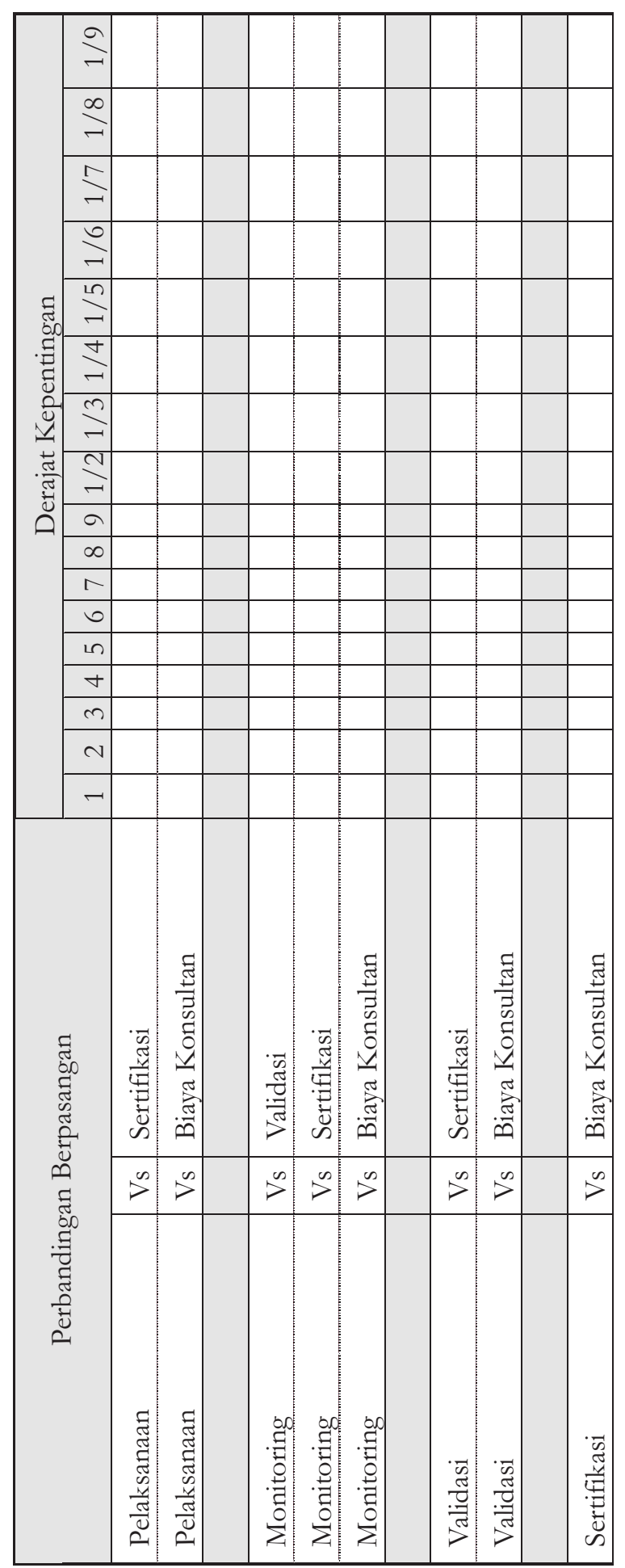

Kelembagaan Aforestasi dan Reforestasi .......... (Kirsfianti Linda Ginoga et al.) 


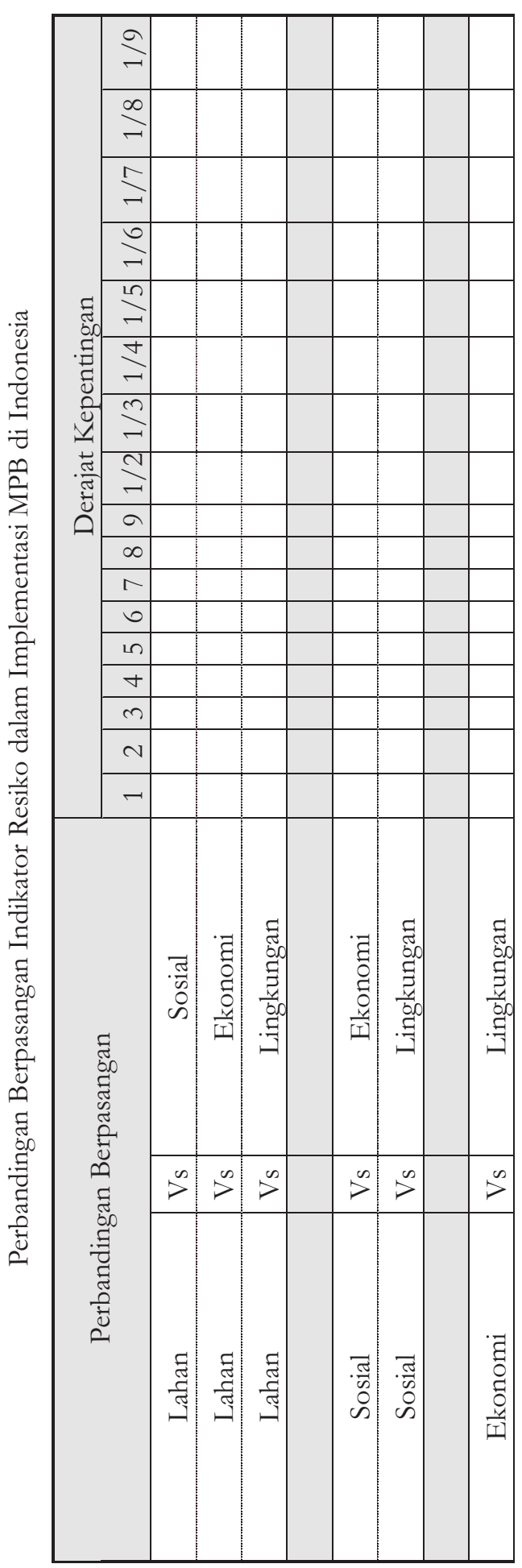


Lampiran 2. Daftar Responden Kelembagaan Karbon di NTB dan Jawa Barat

\begin{tabular}{|c|c|c|c|}
\hline \multirow{2}{*}{ NO } & \multirow{2}{*}{ INSTANSI } & \multicolumn{2}{|c|}{ Jumlah Responden/Jabatan } \\
\hline & & NTB & JAWA BARAT \\
\hline \multicolumn{4}{|c|}{ PROPINSI } \\
\hline 1 & Dinas Kehutanan & $\begin{array}{l}3 \text { (Wakil Kepala Dinas, } \\
\text { Kasubdin Planologi, Staf } \\
\text { Subdin Planologi) }\end{array}$ & $\begin{array}{l}2 \text { (Kepala bidang } \\
\text { Pembinaan dan } \\
\text { Perlindungan, } \\
\text { Penyuluh) }\end{array}$ \\
\hline 2 & $\begin{array}{l}\text { Bapedalda Propinsi/ } \\
\text { BLHD }\end{array}$ & $\begin{array}{l}1 \text { (Kepala Bidang Perijinan } \\
\text { dan Pengendalian } \\
\text { Pencemaran) }\end{array}$ & $\begin{array}{l}2 \text { (Kepala Sub Bagian } \\
\text { Amdal, Pelaksana } \\
\text { Audit Pengendalian } \\
\text { Kerusakan) }\end{array}$ \\
\hline 3 & Bapeda Propinsi & 1 (Kepala Subdin Ekonomi) & $\begin{array}{l}2 \text { (Staf Bidang } \\
\text { Lingkungan) }\end{array}$ \\
\hline 4 & BP DAS & $\begin{array}{l}1 \text { (Kepala Seksi Evaluasi } \\
\text { dan Laporan) }\end{array}$ & $\begin{array}{l}2 \text { (Kepala Seksi } \\
\text { Program, Kepala Seksi } \\
\text { Kelembagaan) }\end{array}$ \\
\hline 5 & Kantor Gubernur & $\begin{array}{l}1 \text { (Kepala Bidang } \\
\text { Pemerintahan) }\end{array}$ & - \\
\hline 6 & $\begin{array}{l}\text { Lembaga Swadaya } \\
\text { Masyarakat (LSM) }\end{array}$ & 1 (Ketua WWF NTB) & - \\
\hline 7 & Perguruan Tinggi & $\begin{array}{l}3 \text { (Dosen Universitas } \\
\text { Mataram) }\end{array}$ & - \\
\hline \multicolumn{4}{|c|}{ KABUPATEN } \\
\hline 8 & Dinas Kehutanan & $\begin{array}{l}2 \text { (Kepala Dinas Kehutanan } \\
\text { Lombok Timur, Kepala } \\
\text { Subdin Program, Dinas } \\
\text { Kehutanan Lombok } \\
\text { Tengah) }\end{array}$ & $\begin{array}{l}4 \text { (Kepala Bidang Tata } \\
\text { Usaha, Pimpro } \\
\text { Gerhan, } 2 \text { Penyuluh } \\
\text { Kehutanan) }\end{array}$ \\
\hline 9 & Bapeda Kabupaten & - & $\begin{array}{l}1 \text { (Staf Bidang } \\
\text { Ekonomi) }\end{array}$ \\
\hline & Jumlah & 13 & 13 \\
\hline
\end{tabular}

